\title{
子宮鏡下手術に子宮内バルーンタンポナーデを用いた胎盤ポリープの8例 -出血のコントロールと妊孕性保持の両立を目指して-
}

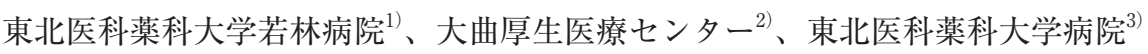 \\ 黑澤大樹 ${ }^{1)}$ 、渡辺 正 $^{1)}$ 、石山美由紀 ${ }^{1)}$ 、設楽明宏 ${ }^{2}$ 、 \\ 長尾大輔 ${ }^{2)}$ 、中西 透3)、深谷孝夫 ${ }^{3)}$ 、渡部 洋 ${ }^{3)}$
}

\section{Use of intrauterine balloon tamponade in hysteroscopic surgery for placental polyps: a report of 8 cases}

\author{
Hiroki Kurosawa $^{1)}$, Tadashi Watanabe ${ }^{1)}$, Miyuki Ishiyama ${ }^{1)}$, Akihiro Shitara ${ }^{2}$, \\ Daisuke Nagao $^{2)}$, Toru Nakanishi ${ }^{3)}$, Takao Fukaya ${ }^{3)}$, Yoh Watanabe ${ }^{3)}$ \\ Department of Obstetrics and Gynecology, Tohoku Medical and Pharmaceutical University Wakabayashi Hospital ${ }^{1)}$, \\ Department of Obstetrics and Gynecology, Omagari Kousei Medical Center ${ }^{2}$, \\ Department of Obstetrics and Gynecology, Tohoku Medical and Pharmaceutical University Hospital ${ }^{3)}$
}

\begin{abstract}
Objective: To assess the efficacy of careful surgical technique and intrauterine balloon tamponade in preventing abnormal bleeding in hysteroscopic surgery for placental polyps

Design: Retrospective study

Setting: Single-institution case series

Patients: Patients with placental polyps who underwent hysteroscopic surgery

Intervention: Hysteroscopic resection with intrauterine balloon tamponade

Main outcome: Perioperative surgical complications including abnormal bleeding

A total of 8 patients were treated using hysteroscopy. The mean patient age was 40.1 years (range: $34-44$ years), the median diameter of the placental polyp was $23 \mathrm{~mm}$ (range: 7-46 mm), and the median surgical time was 32 min (range: 10-65 min). Hysteroresectoscopes with 22 or 26 Fr diameters were used to carefully cauterize individual blood vessels at the base of placental polyps with a flat-type loop electrode. Two cases required temporary compression hemostasis with an intrauterine balloon during the intraoperative period because of increased bleeding. Although 2 cases experienced $100 \mathrm{~g}$ and $80 \mathrm{~g}$ of blood loss, the other 6 cases did not have abnormal bleeding during the perioperative period when treated with intrauterine balloon tamponade for a day after hysteroscopic surgery.

Conclusion: Placental polyps can be safely treated by hysteroscopic resection through careful surgical technique and intra- and/or postoperative application of intrauterine balloon tamponade.
\end{abstract}

Key words: placental polyp, hysteroscopic resection, intrauterine balloon tamponade

\section{【緒 言】}

胎盤ポリープは、分娩後や流産後に遺残した絨 毛組織にフィブリン沈着や血管浸潤が生じて形成 される腫瘤性病変であるが、不妊治療による妊娠、 流産後に発症リスクが増加する報告も認められ る ${ }^{1)}$ 。一般的には妊娠終了後数週間経ってから性
器出血により診断されることが多いが、無症状の うちに超音波検査にて血流豊富な腫瘤 ${ }^{2)}$ として発 見されることもある。胎盤ポリープに対しては性 器出血の改善のため子宮全摘も考慮されるが、妊 孕能温存治療として、子宮鏡下切除術 (hysteroscopic resection) と子宮動脈塞栓術 (uterine artery embolization: UAE) の併用 ${ }^{2-8)}$ 、 
メソトレキセート投与 ${ }^{9,10)}$ および自然待機 4.9$)$ など の報告がある。しかし、UAEの併用は術後疼痛 管理や、妊孕能低下 ${ }^{11)}$ 、卵巣機能低下 ${ }^{12)}$ 、癒着胎 盤発症 ${ }^{13)}$ 抢よび子宮破裂 ${ }^{13-15)}$ などの合併症が危 惧される。また、メソトレキセート投与や自然待 機は性器出血のリスクと共に、治癒までには一定 の期間を要するため ${ }^{4)}$ 、特に不妊治療中の場合は 不要な時間的口スを招くこととなる。

今回我々は、注意深い子宮鏡下手術操作、なら びに術中および術後の子宮内バルーン圧迫併用に より、周術期多量出血をきたすことなく治療しえ た胎盤ポリープ症例 8 例を経験したので報告す る。

\section{【対象】}

2013年 4 月より 2018年 4 月の期間に当院で診断 し、子宮鏡下手術を行った胎盤ポリープ 8 例を対 象とした。

今回検討を行った 8 症例について表 1 、表 2 に 示した。症例の平均年齢は40.1歳 $(34-44$ 歳)、 先行妊娠は、自然妊娠 2 例、新鮮肧移植後妊娠が 3 例、凍結融解肧移植後妊娠が 3 例であった。 8 例中 7 例が妊娠 $6-9$ 週の初期流産であり、 5 例 では流産手術を施行されており、2 例は妊卵自然 排出後、 1 例は 7 週人工妊娠中絶術後であった (表 1)。妊娠終了から診断までの期間の中央值は 21.5日（分布：5-102日）、5 例に性器出血を認

表1 各症例の臨床的背景

\begin{tabular}{|c|c|c|c|c|c|}
\hline 症例 & 年齢 & 妊娠歴 & 子宮手術歴 & 妊娠方法 & 先行妊娠 \\
\hline 1 & 34 歳 & 4 妊 1 産 & TCR (内膜ポリープ) & 凍結融解胚移植 & 8 週流産 (流産手術) \\
\hline 2 & 40 歳 & 1 妊 0 産 & なし & 凍結融解胚移植 & 8 週流産 (流産手術) \\
\hline 3 & 44 歳 & 2 妊 0 産 & TCR (粘膜下筋腫) & 新鮮胚移植 & 8 週流産(自然排出) \\
\hline 4 & 43 歳 & 2 妊 0 産 & 流産手術 & 新鮮胚移植 & 6 週流産 (自然排出) \\
\hline 5 & 42 歳 & 1 妊 0 産 & なし & 新鮮胚移植 & 9 週流産 (流産手術) \\
\hline 6 & 37 歳 & 1 妊 0 産 & なし & タイミング法 & 6 週流産 (流産手術) \\
\hline 7 & 42 歳 & 2 妊 1 産 & なし & 凍結融解胚移植 & 8 週流産 (流産手術) \\
\hline 8 & 39 歳 & 2 妊 1 産 & なし & 自然妊娠 & 7 週人工妊娠中絶 \\
\hline
\end{tabular}

表2 検討症例

\begin{tabular}{ccccc}
\hline 症例 & 腫瘤径 & 血流 & 出血量 & 術中バルーン使用 \\
\hline 1 & $22 \mathrm{~mm}$ & 豊富 & 少量 & - \\
2 & $46 \mathrm{~mm}$ & そしい & 少量 & - \\
3 & $30 \mathrm{~mm}$ & 豊富 & 少量 & - \\
4 & $24 \mathrm{~mm}$ & 豊富 & 100g & + \\
5 & $15 \mathrm{~mm}$ & 豊富 & 少量 & + \\
6 & $27 \mathrm{~mm}$ & 豊富 & 80g & - \\
7 & $7 \mathrm{~mm}$ & 豊富 & 少量 & \\
8 & $18 \mathrm{~mm}$ & そしい & 少量 & -
\end{tabular}


めたが、3例では自覚症状を認めなかった。診断 時の血清hCG值は中央值 $193 \mathrm{mIU} / \mathrm{ml} （ 2-3475$ $\mathrm{mIU} / \mathrm{ml}$ ) であった。平均腫瘤径の中央值は $23 \mathrm{~mm}(7-46 \mathrm{~mm})$ 、診断時は 8 例中 7 例に超音 波断層法カラードップラー所見で子宮壁よりポリ ープ内部へ入り込む豊富な血流を認めた（図 $1 a$, b）が、手術までの待機期間が最も長かった 1 例 (症例 8 ) では経過中に血流が著明に減少した（表 2 )。 8 例中 5 例では造影MRI検査も行い、flow voidを伴い強く造影される腫瘤を認め、子宮内腔 に突出し筋層浸潤所見がないことを確認した（図 $1 \mathrm{c}, \mathrm{d})$ 。なお、血流のそしい 2 例と腫瘤径が小さ い 1 例にはMRI検査は施行しなかった。全例に子 宮鏡検査も行い、腫瘤のサイズ、性状、付着部位、 付着部の血管構造などを術前に観察した（図 2 )。

\section{【子宮鏡下手術手技】}

子宮鏡下手術当日朝に吸湿性子宮頸管拡張器を 子宮腔内に挿入した。手術は、全身麻酔下に行い、
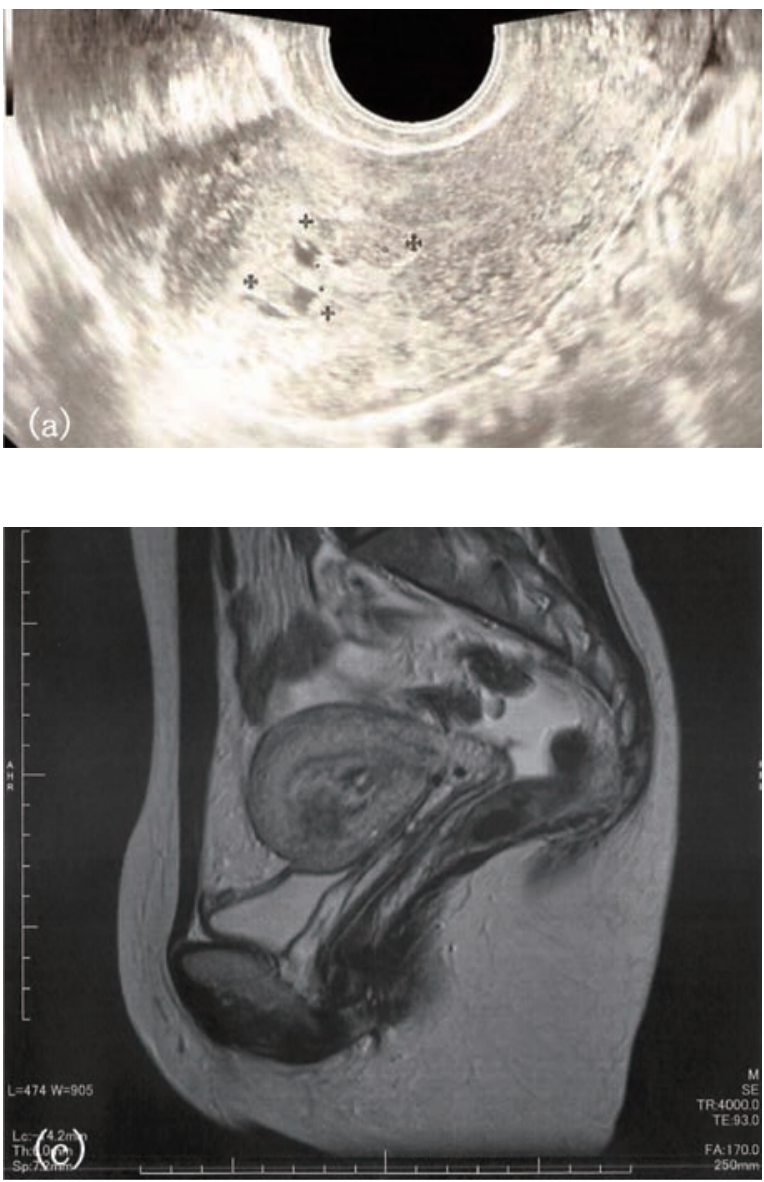

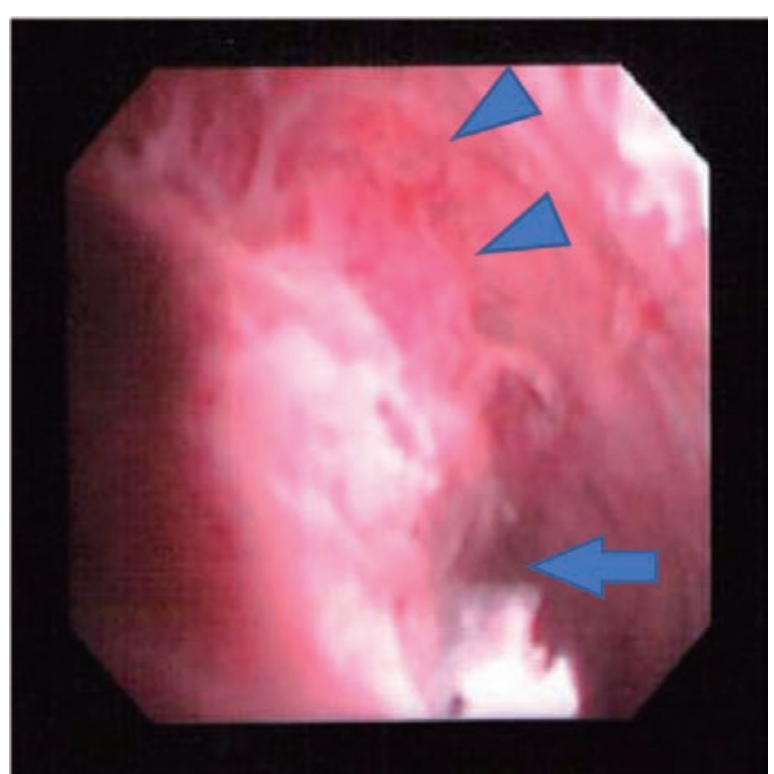

図2 術前の子宮鏡検査による胎盤ポリープ基部の血管構造（症例 6)。

胎盤ポリープは12時方向より発生し、細径の血管束が形成さ れている。矢印：胎盤ポリープ、矢頭：胎盤ポリープ基部の 血管。
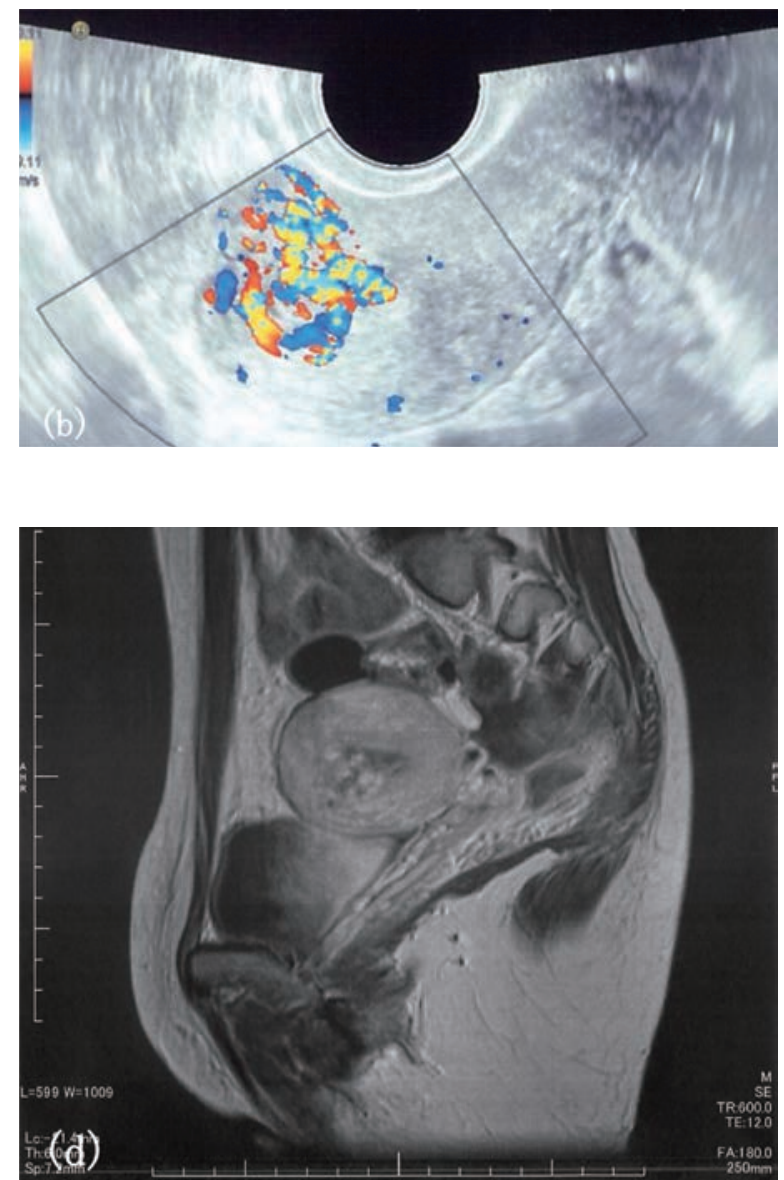

図1 経腟超音波断層法カラードップラーおよび造影MRI所見（症例6）。

(a) 経腟超音波断層法。子宮内腔に内部やや不均一な腫瘤を認める。(b) 経腟超音波断層法カラードップラー所見。子宮前壁より子宮内腔 の腫瘤に入り込む豊富な血流を認める。(c) 単純MRI（矢状断）。子宮内腔に突出した腫瘤を認め、子宮前壁より連続するflow voidを認める。 筋層浸潤所見は認めない。(d) 造影MRI（矢状断）。腫瘤は筋層と同等に造影されている。 

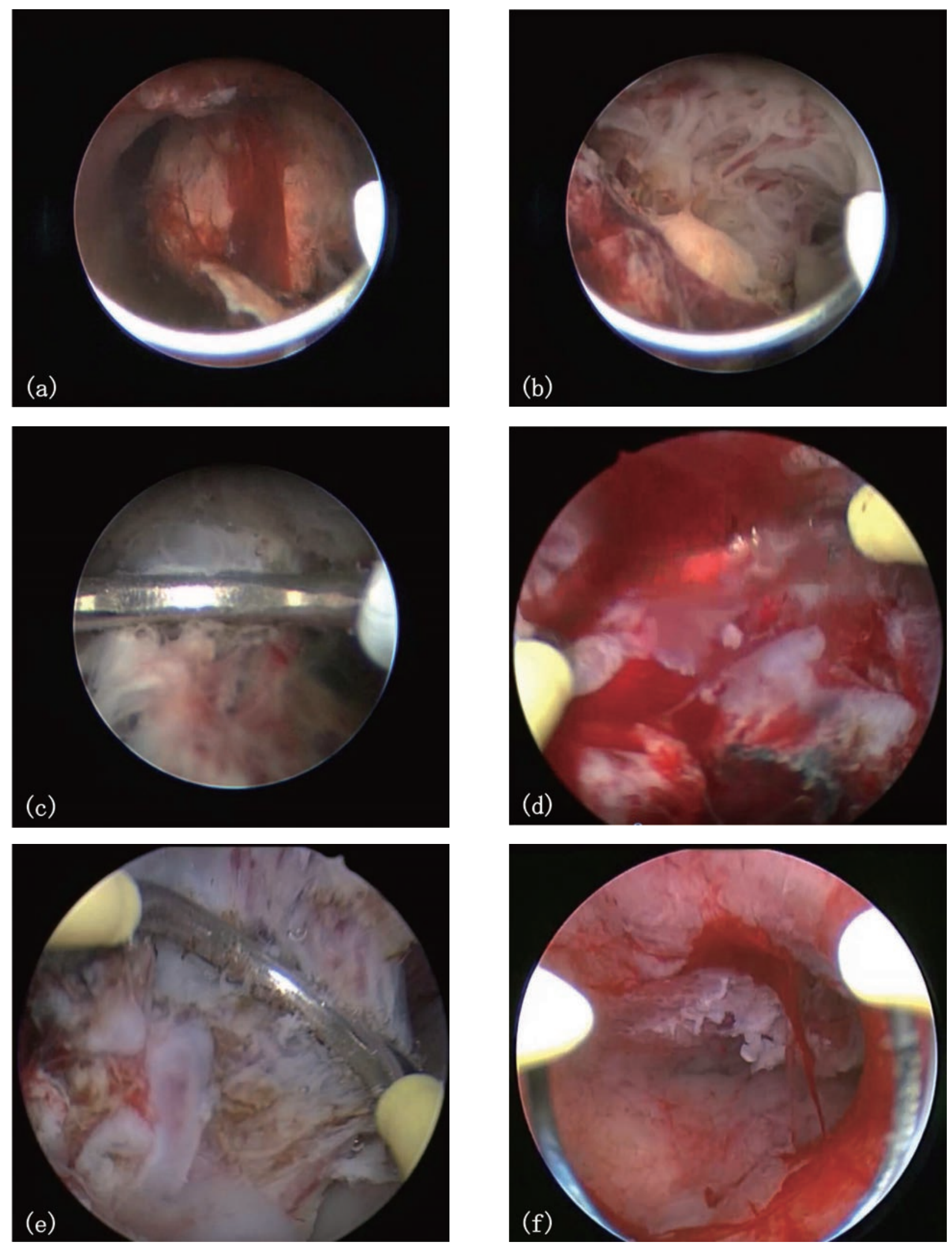

図3子宮鏡下手術所見（症例6）。

（a）胎盤ポリープの観察、(b) 胎盤ポリープ基部の血管束、(c) 胎盤ポリープ基部の凝固、（d）胎盤ポリープ基部の血管からの出血、(e) 子宮内バルーン圧迫による一時的な止血後に子宮鏡下手術再開、( $f$ ) 手術終了時。

(a) $\sim$ (c) : 22Fr hysteroresectscope、(d) $\sim$ ( $\mathrm{f}): 26 \mathrm{Fr}$ hysteroresectscope。 
ヘガール拡張器による頸管拡張操作から手術操作 中、経腹超音波断層法による観察を継続して行っ た。22Frまたは26Fr hysteroresectoscope（Karl Storz社）を用いて子宮内腔を観察し、胎盤ポリ ープの形状（図3a）、サイズ、付着部位、基部の 血管構造（図3b）などを確認した。胎盤ポリー プの切除では、フラット型ループ電極を用いて、 凝固モード、出力 $60 \mathrm{~W} て ゙$ 腫瘤基部の血管を 1 本ず つ凝固するように丁寧に処理（図3c）した後、腫 瘤と子宮壁との間を少しずつ前進しながら剥離し た。手術操作中に出血の増加が認められる場合 (図 3d）は、16Frバルーンカテーテル（バーデック ス シルバールブリキャスフォーリーカテーテ ル、メディコン社）（図4a）により数分間圧迫止 血を行い、止血確認後に子宮鏡下手術操作を再開 した（図3e）。腫瘤を大部分子宮壁から剥離した ところで、胎盤鉗子、あるいはアングル型のルー プ電極で腫瘤を搬出した。残存腫瘤を認めた場合 は、アングル型のループ電極で切除を追加した。
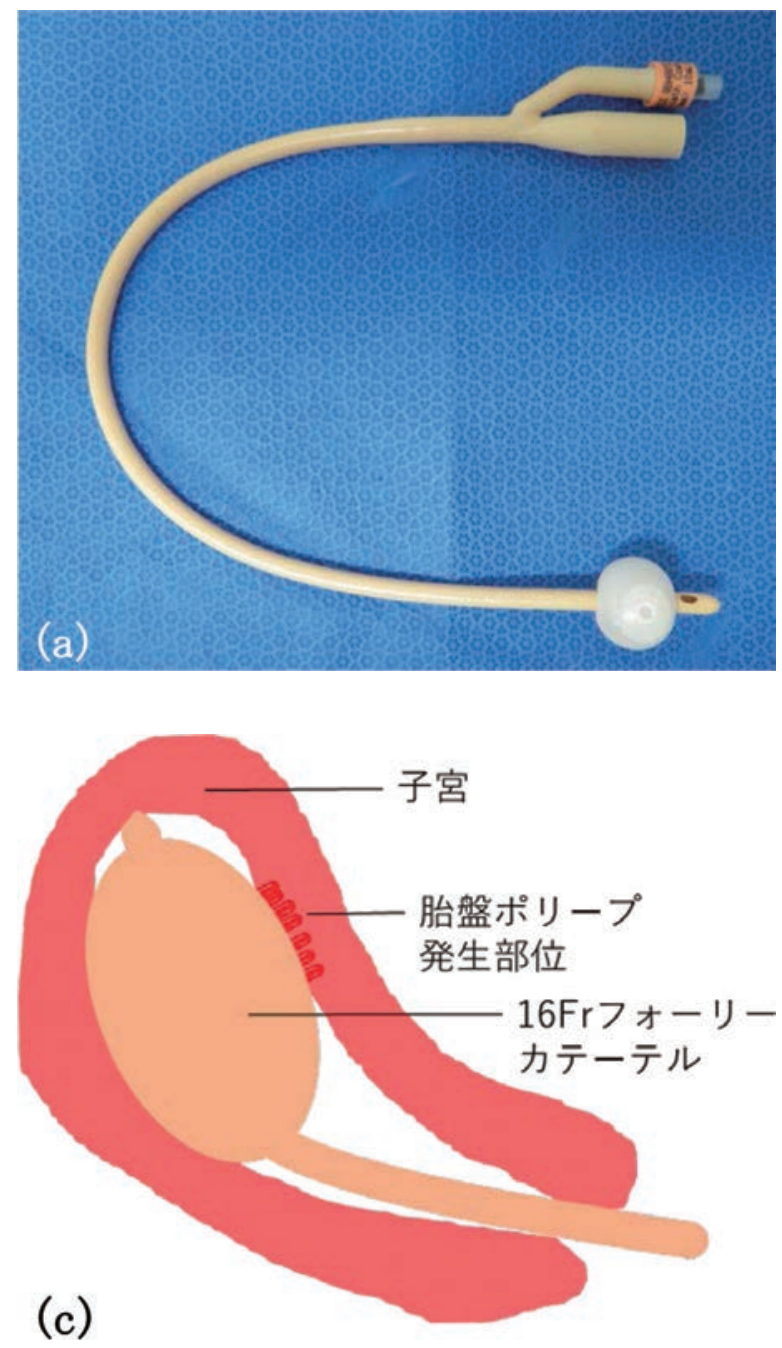

胎盤ポリープ切除後の凝固止血操作は最小限と し、動脈性出血のないことを確認した（図3f）上 で16Frバルーンカテーテルを子宮腔内に翌日ま で留置した。子宮内バルーンカテーテル挿入の際 には、経腹超音波断層法で観察しながらバルーン が胎盤ポリープ発生部位に一致するように調節し た（図 $4 \mathrm{~b}, \mathrm{c}$ )。

\section{【結 果】}

手術時間は平均32分 (10-65分)、摘出重量は 平均 $7 \mathrm{~g}(1-29 \mathrm{~g})$ であった。 8 例中 2 例では、 出血増加のため、術中に子宮内バルーンカテーテ ル挿入による一時的な圧迫止血を行った。出血量 は最も多い症例で $100 \mathrm{~g}$ 、次いで $80 \mathrm{~g}$ 、残りの 6 症 例は少量でありカウントできなかった（表 2$) 。$ 術前後のへモグロビン值の低下は平均 $1.3 \mathrm{~g} / \mathrm{dl}(0.5$ $-2.4 \mathrm{~g} / \mathrm{dl}$ ) であった。手術終了時に挿入した子 宮内バルーンカテーテルのバルーン内注入量は平 均 $6.7 \mathrm{ml}(5-10 \mathrm{ml})$ であった。子宮内バルーン

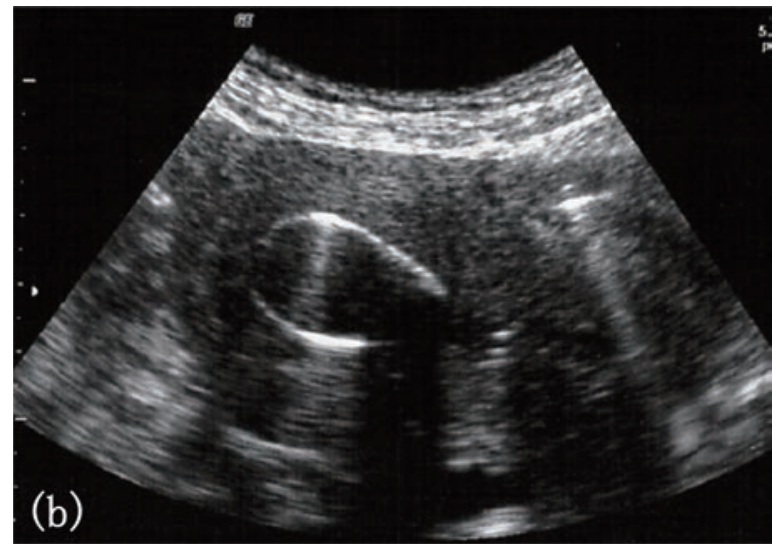

図4 16Frバルーンカテーテル。

(a) 16Frバルーンカテーテル (バーデックス シルバールブリ キャスフォーリーカテーテル、メディコン社)、(b) (c) 子 宮内バルーンカテーテル挿入 (b:経腹超音波断層法、c:説明図)。 
カテーテルは翌日に抜去した。すべての症例で術 後の異常出血や合併症はなく、再手術やUAE、 MTX、輸血などの追加治療を要した例はなかっ た。摘出標本では、全例で病理組織学的に絨毛成 分の存在を確認した。術後は 5 例に子宮内癒着予 防目的に子宮内避妊具 $\left(\mathrm{FD}-1^{\circledR}\right.$ 、不二ラテックス 社）を挿入した。術後 $2-3$ ケ月後に外来で FD-1を抜去した。 4 例には外来で子宮鏡検査を 行ったが、子宮内癒着をきたした例はなかった。 術後 $3-4$ ヶ月の診察後に妊娠を許可し、挙児希 望のある 7 例は不妊治療再開目的に前医へ逆紹介 とした。1例に自然妊娠が成立し、現在まで妊娠 経過は順調である。

\section{【考察】}

産科婦人科用語集・用語解説集によると、胎盤 ポリープは「残留胎盤片から発生した子宮腔内の ポリープで、凝血などが加わって次第に増大する。 産後数週から数力月後に出血を起こすことがあ る」と説明されている ${ }^{16)}$ 。鑑別疾患として、胎盤 遺残・絨毛遺残、仮性動脈瘤などが挙げられる。 胎盤ポリープも遺残した胎盤組織より発生する疾 患であり、胎盤ポリープと胎盤遺残を一括して retained placentaとして扱われる場合もある。胎 盤遺残は妊娠終了直後より観察されるのに対し、 胎盤ポリープは血管浸潤、フィブリン沈着・硝子 化が起こることにより、妊娠終了からある一定の 時間を経て発生・増大する。仮性動脈瘤は、子宮 手術や子宮内操作、分婏などの際に動脈壁の一部 が損傷することにより生じ、血流豊富な腫瘤性病 変である点が胎盤ポリープと共通している。超音 波断層法で「周囲を高輝度エコー領域に覆われた 低輝度エコー部」として描出され、低輝度部分は カラードップラー所見で血流が確認できる。ダイ ナミックCTにて早期相で強く造影され、出血を きたしている場合には造影剂の血管外漏出 （extravasation）を認め、治療方針の参考になる とされる ${ }^{17)}$ 。胎盤ポリープの発生頻度は $0.05-$ $5.3 \%$ 稀な疾患とされているが18)、今回の自験例 では 8 例中 6 例がARTにより成立した妊娠・初 期流産後に発生しており、ARTに続発する症例 が増加している可能性も考えられた。実際、 ARTによる妊娠では胎盤ポリープの発生頻度が 高い(1) だけでなく、出血性ショックとなりUAE を要するケースも多い ${ }^{19)}$ という報告がある。

胎盤ポリープに対する子宮鏡下切除術では、 UAEを併用した報告が多く、出血量軽減の有用
性は高いと思われる。しかし、UAE施行により 卵巣機能低下 ${ }^{12)}$ PAsherman症候群 ${ }^{20)}$ 、不妊 ${ }^{11)}$ な ど妊孕性が低下する可能性がある。さらに、 UAE施行後の妊娠では、流早産 ${ }^{21)}$ 、癒着胎盤 ${ }^{13)}$ 、 子宮破裂 ${ }^{13-15)}$ などの重大な妊娠合併症の報告もあ る。貞森らの報告 ${ }^{22)}$ のように子宮鏡単独治療に より出血増量をきたし輸血を要するリスクがある のは確かだが、術中出血を憂慮するあまり後々の 合併症を考慮せずUAEが施行されているケース も少なくないと思われる。今回報告した 8 例中 7 例は挙児希望のため不妊治療専門クリニック通院 中の妊娠であり、前医である程度の経過観察期間 を経た後に、子宮鏡下治療を含めた加療目的に当 院に紹介となった。年齢的要因もあり、次回妊娠 に対して医原的な合併症のリスクを避けながら早 期に治療を完了させる必要があった。術前の子宮 鏡、MRI検査で腫瘤に豊富な血流を認めた例にお いても、出血は多量とまではいえない状況であり、 全 8 例とも子宮鏡下治療前にUAEは施行しなか った。子宮鏡下治療では、出血のコントロールと 妊孕性の保持を同時に満たす手技が理想的と考え られる。胎盤ポリープに対する子宮鏡下手術の手 技について詳細に記載されている報告は少ない。 ただし、一度大出血に遭遇すると止血操作は容易 ではなく、頻回の凝固が必要になり、子宮穿孔の 危険性も高くなると思われる。そのため、大量出 血をきたさないように注意を払いながら手術を行 うことが大変重要であると考えている。我々は、 可能であれば径の細い22Fr hysteroresectscope で手術を開始している。22Fr hysteroresectscope は頸管拡張が不十分な場合や子宮内腔の屈曲が強 い場合でも挿入しやすく、細部まで先端を進める ことが可能であり、組織への不必要な接触を避け ることができる。腫瘤が大きい場合や、剥離を行 うスペースが広がるなどの条件が満たされた場合 には、26Fr hysteroresectscopeに置き換えて手 術を行う場合もある。

胎盤ポリープでは基部に細径の血管が密集して いるが、これらを 1 本ずつ凝固したのちに、少し ずつ組織の剥離を行うことが重要である。特にフ ラット型電極は、アングル型電極よりも腫瘤の剥 離の方向に一致して角度を合わせやすく、アング ル型電極では到達できない狭いスペースにも電極 を装着することが可能である。フラット型電極で は、子宮壁と腫瘤との間を手前側から奥側へ向か って少しずつ無通電に前進剥離していくことによ り、出血する可能性のある血管を確認しながら処 
理することが可能となる。

自験例では超音波断層法カラードップラー所見 で血流豊富と認識されていても実際には太い血管 ではなく複数の血管束であることが多く、血管を 1 本ずつ処理する方法でほとんどの場合、対応す ることができた。

症例 5 、症例 6 では、術中出血により視野が不 良となり、子宮内バルーンを挿入したが、数分間 の圧迫で止血に至り、子宮鏡下手術を完遂した。 症例 5 は子宮後屈症例で、 hysteroresectscopeの 可動域が狭い例であった。症例 6 は術者が胎盤ポ リープに対する子宮鏡下手術をはじめて執刀した ケースであった。視野不良などで子宮鏡下手術を 行うための条件が悪化した場合には、術中に子宮 内バルーンを挿入することで良好な視野を再現す ることが可能となった。一方、胎盤ポリープに対 する子宮鏡下手術には慣れも必要であり、子宮鏡 下手技の修練を積むことも必要であると考えられ た。

子宮鏡下手術の合併症として出血のほかにもう 一つ注意すべきものとして、子宮穿孔がある。子 宮鏡下手術における術中、術後合併症報告では、 胎盤ポリープに対する手術は子宮内腔癒着剥離術 についで子宮穿孔の頻度が高いことがアンケート 調查の結果から明らかになって抢り ${ }^{23)}$ 、粘膜下筋 腫や子宮内膜ポリープに対して行う子宮鏡下手術 よりもリスクがあることを意識して手術を行うこ とが重要である。経腹超音波断層法を併用するの はもちろんのことだが、フラット型電極は手前側 で操作すること、特に凝固 (切開) 操作と前進に よる無通電の剥離操作を必ず分けて行うことを徹 底することが重要である。さらに、視野が不良な 状況で無理に剥離や止血操作を続行しない、子宮 筋層まで切り达まないなど注意が必要である。 我々の経験では、子宮壁に固着している部分まで 切除しなくとも術後の血清hCG值の下降は良好で 腫瘤陰影は消失しており、追加治療を必要とした 例も経験していない。

胎盤ポリープ切除後の子宮内腔の凝固止血は、 出血が少量の場合は行っていない。少量の出血は、 手術終了時に子宮内にバルーンを留置することで 圧迫止血にいたる。我々の経験した 8 症例では術 後の異常出血や合併症は発生しなかった。むしろ、 妊孕性の保持という観点から、過剩な子宮内膜の 凝固は好ましくないと考えている。

今回の検討症例では、術中出血が多かった 2 例 （症例 4 、症例 6 ）ではバルーン容量 $8 \mathrm{ml} 、 10 \mathrm{ml}$
としたのに対し、術中出血が比較的落ち着いてい た他の症例では $5-6 \mathrm{ml}$ とした。術中のみなら ず、術後の子宮内バルーン圧迫も簡便でかつ確実 性の高い止血法であり、合併症のリスクも低い優 れた方法であると考えている。実際、婦人科疾患 による子宮出血に対して、フォーリーカテーテル による圧迫止血の有効性についての報告もいくつ かみられる ${ }^{24-25)}$ 。

当科では本治療に対する明確な除外基準は定め ていないが、術前MRIで子宮筋層媣くに病変が浸 潤していないこと、子宮鏡検査で胎盤ポリープに 矛盾しない所見であること、TCRによる凝固止 血操作が明らかに不可能と思われるような異常に 太い血管がないことなどを術前に確認している。 緊急止血を要するような出血持続例はなかったた め本法がそのような症例に対して有効か明らかで はないが、出血症状の落ち着いている胎盤ポリー プであれば、術前の画像診断で血流豊富な場合で も術中子宮内バルーン圧迫を併用した子宮鏡下手 術により治療を完遂できる可能性が高いと考えら れる。術後には子宮内避妊器具を外来で抜去した 後に4例にセカンドルック子宮鏡検査を行ったが、 子宮内癒着をきたした例はなく、内膜欠損も認め られなかった。

胎盤ポリープ治療後の妊娠における再発や癒着 胎盤などのリスクについて、胎盤ポリープ治療中 /治療後の 3 症例 4 妊娠のうち、 2 症例で胎盤ポ リープ再発を認めたという報告 ${ }^{26)}$ や、胎盤ポリ ープに対しUAEによる治療を行った後の妊娠で 癒着胎盤を生じたという報告 ${ }^{27)}$ がある。また、 分婏または流産・中絶後に発生した妊娠成分遺残 (Retained products of conception; RPOC) に対 して吸引掻爬または子宮鏡を用いて治療を行い、 その後の妊娠におけるRPOC再発について検討し た報告では、15.5\%にRPOCの再発がみられ、 $27.3 \%$ に分娩第 3 期の胎盤異常 (胎盤遺残や癒着 胎盤など）がみられた ${ }^{28)}$ 。したがって、胎盤ポリ ープ治療後の妊娠については、胎盤ポリープ再発 や癒着胎盤などの胎盤異常に注意が必要と考えら れる。

今後は術後の妊娠率や妊娠までの期間、妊娠転 帰なども含め他の治療方法と比較検討する必要が ある。そのうえで、妊孕性温存が必要な胎盤ポリ ープ症例に対する標準的な治療法を検討していく 必要があると思われる。 


\section{【結語】}

胎盤ポリープ 8 例について、術中の注意深い操 作、ならびに術中および術後に子宮内バルーン圧 迫を併用した子宮鏡下手術により大量出血をきた すことなく治療を完遂できた。本法は、適切な症 例の選択により、胎盤ポリープに対して出血のコ ントロールと妊孕性の保持を両立させることが可 能な術式であると考えられる。

すべての著者は開示すべき利益相反はない。

\section{【参考文献】}

1) Baba T., et al.: Assisted reproductive technique increases the risk of placental polyp, Gynecol Endocrinol, $2013 ; 29$ (6) : 611-614.

2 ) Sorano S., et al.: Choosing the uterine preservation surgery for placental polyp determined by blood flow evaluation: A retrospective cohort study, Ann Med Surg (Lond), $2017 ; 23: 13-16$.

3 ) Takeuchi K., et al.: Pregnancy outcome of uterine arterial embolization followed by selective hysteroscopic removal of a placental polyp、 Acta Obstet Gynecol Scand, 2007 ; 86 (1) : 22-25.

4）菅野 素子、他：胎盤ポリープに対して、子宮動脈塞 栓術と子宮鏡下切除術を併用し治療した症例と経過 観察で消失した症例の検討、日本産科婦人科内視鏡 学会雑誌、2016；32：152-156.

5 ) 平野 茉来、平池 修：【産科大出血に慌てない!!】知 っておくべき疾患別対処法 胎盤ポリープ、臨床婦人 科産科、2016；70（3）：321-325.

6 ）西田 正和、他：子宮鏡下手術により子宮を温存し得 た胎盤ポリープの5症例の検討、日本産科婦人科内視 鏡学会雑誌、2014；30（1）：253-257.

7 ）亀田 里美、他：胎盤ポリープの4症例、仙台市立病 院医学雑誌、2014；34：25-30.

8 ）高橋 也尚、他：子宮動脈塞栓または内腸骨動脈閉塞 を施行後、子宮鏡下手術で切除しえた胎盤ポリープ の3症例、日本産科婦人科内視鏡学会雑誌、2010；26 (2) : 550-555.

9 ) 南 晋、他：待機療法を行った胎盤ポリープ2症例の 検討、現代産婦人科、2016；65（1）：75-79.

10）滝戸 なほみ、他：子宮内容除去術後に発生した胎盤 ポリープに対してMethotrexate全身投与が奏効した1 例、東京産科婦人科学会会誌、2014；63（1）：99103.

11) Torre A., et al.: Uterine artery embolization for severe symptomatic fibroids: effects on fertility and symptoms, Hum Reprod, 2014 ; 29 (3) : 490-501.

12) Czuczwar P., et al: Comparison of the influence of three fibroid treatment options: supracervical hysterectomy, ulipristal acetate and uterine artery embolization on ovarian reserve - an observational study, J Ovarian Res, 2018 ; 11 (1) : 45.

13) Yeaton-Massey A., et al.: Uterine rupture after uterine artery embolization for symptomatic leiomyomas, Obstet Gynecol, 2014 ; 123 (2 Pt 2 Suppl 2) : 418-420.

14) Takeda J., et al.: Spontaneous uterine rupture at 32 weeks of gestation after previous uterine artery embolization, J Obstet Gynaecol Res, 2014 ; 40 (1) : 243-246.

15) Shashoua A. R., et al.: Ischemic uterine rupture and hysterectomy 3 months after uterine artery embolization, J Am Assoc Gynecol Laparosc, 2002 ; 9 (2) : 217-220.

16）日本産科婦人科学会 編：産科婦人科用語集 - 用語 解説集 改訂第4版、2018；。

17）馬場 洋介：【想起できるかが分かれ道! 知っておき たい母体合併症】仮性動脈瘤、産婦人科の実際、 $2018 ; 67$ (1) : 65-68

18）小林 博：産後の出血の原因としての胎盤ポリープに ついて、助産婦、1990；44（10）：5-10.

19) Miyahara Y., et al.: In vitro fertilization-embryo transfer pregnancy was a risk factor for hemorrhagic shock in women with placental polyp, Gynecol Endocrinol, 2014 ; 30 (7) : 502-504.

20) Song D., et al.: A matched cohort study comparing the outcome of intrauterine adhesiolysis for Asherman's syndrome after uterine artery embolization or surgical trauma, J Minim Invasive Gynecol, 2014 ; 21 (6) : 1022-1028.

21) Goldberg J., Pereira L., Berghella V. : Pregnancy after uterine artery embolization, Obstet Gynecol, $2002 ; 100$ (5 Pt 1) : 869-872.

22）貞森 理子、他：子宮鏡下手術で治療し得た胎盤ポリ 一プ9例の検討、日本産科婦人科内視鏡学会雑誌、 2007 ; 22 (2) : 371-374.

23）日本産科婦人科内視鏡学会雑誌Vol.34. No.1/4月号.

24) Nishino Kimihiro, et al.: Effective salvage of acute massive uterine bleeding using intrauterine balloon tamponade in a uterine adenomyosis patient on dienogest, The Journal of Obstetrics and Gynaecology Research, 2013 ; 39 (3) : 738-741.

25）馬場 征一、他：Balloon tamponadeで止血した子宮 動静脈奇形の1例、沖縄産科婦人科学会雑誌、2013 ; $35: 90-95$.

26）藤村 大志、他：経過観察が可能であった胎盤ポリー プ症例の検討、現代産婦人科、2018；66（2）：335338.

27）菊地 恵理子、他：胎盤ポリープ治療後妊娠における 帝王切開時子宮出血に対して子宮圧縮縫合術を要し た1例、東京産科婦人科学会会誌、2017；66（3）: 544-548.

28) Smorgick N., et al.: Retained products of conception: 
What is the risk for recurrence on subsequent pregnancies? Eur J Obstet Gynecol Reprod Biol, $2018 ; 224: 1-5$.

投稿日：2018年10月27日

採択日：2018年12月29日 